$E$
51

N422

NMAI

CONTRIBUTIONS FROM THE

$\checkmark .7$ n 0.6 MUSEUM OF THE AMERICAN INDIAN

HEYE FOUNDATION

Volume VII, No. 6

\title{
POLYCHROME GUANACO CLOAKS OF PATAGONIA
}

BY

S. K. LOTHROP

NEW YORK

MUSEUM OF THE AMERICAN INDIAN

HEYE FOUNDATION

I929 

CONTRIBUTIONS FROM THE

MUSEUM OF THE AMERICAN INDIAN

HEYE FOUNDATION

Volume VII, No. 6

\section{POLYCHROME GUANACO CLOAKS OF PATAGONIA}

BY

S. K. LOTHROP

NEIV YORK

MUSEUM OF THE AMERICAN INDIAN HEYE FOUNDATION

1929 



\title{
POLYCHROME GUANACO CLOAKS OF PATAGONIA
}

\author{
BY
}

\section{S. K. LOTHROP}

$\circlearrowleft$ OUTH American Indians, for protection against the cold, employed a cloak, a poncho, or a shirt. The genetic relationship between these garments is close, as the poncho is merely a cloak with a hole in the middle for inserting the head, while a shirt is a poncho which has been sewn up the sides. Poncho and shirt are typical of all western South America from Colombia to central Chile. ${ }^{1}$ Robes, on the other hand, are a southern element of culture, found from Cape Horn northward to the Gran Chaco. The distribution of fur robes as given by Nordenskiöld ${ }^{2}$ includes the following tribes:

$\begin{array}{ll}\text { Mataco } & \text { Yaro } \\ \text { Ashluslay } & \text { Chaná } \\ \text { Toba } & \text { Tehuelche } \\ \text { Abipon } & \text { Ona } \\ \text { Mbayá } & \text { Yahgan } \\ \text { Querandí } & \text { Alacaluf } \\ \text { Lengua } & \text { Chono } \\ \text { Southern Tupinambá } & \text { Araucan } \\ \text { Charrúa } & \text { Arica (prehistoric) }\end{array}$

To this list we may add the Haush of Tierra del Fuego, the Puelche of the Argentine Pampas, and various tribes of the lower Paraná such as the Minuané, Chaná-Mbeguá, Timbú, etc. In short, fur robes have a continuous distribution over thirty-six degrees of latitude in southern South America.

Granted a wide distribution of even such simple cultural elements

1 Nordenskiold (1919, pp. 95-107) has discussed the typology and distribution most adequately. Except in a few minor details we have followed his data.

${ }^{2}$ Ibid., map 15 and pp. 97-98. We have omitted literary sources on which this list is based. 
as the fur mantle, we should naturally expect to find much variation in materials, methods of manufacture, and manner of use. Among the Canoe Indians of Tierra del Fuego, robes were made typically of seal- or otter-skin, and were worn with the fur side outward. Eastern Yahgan at times also used guanaco, while western Yahgan and Alacaluf employed coypu-skins. The stitching was of whale sinew. A characteristic feature of all Magellanic mantles is their small size, for they measure about 35 by 50 inches and covered only the upper part of the body, being held in place with thongs tied across the shoulders. Yahgan capes, to the knowledge of the writer, never received painted decoration on the skin side, but an Alacaluf cape of three coypu-skins, secured for the Museum in I925 (I4/2252), had been painted red.

Ona mantles were made of two or three skins of adult guanaco sewn together with sinews from the back of this animal. They measure about five feet square, which is enough to envelop the body from neck to ankle. Ona women painted their robes red on the skin side, which was worn next the body, and, when this task was finished, they turned the fur side uppermost to wipe their encrimsoned hands. Thus streaks were produced on the fur, but in no way could they be regarded as deliberately made patterns. In fact, the only fields for painted decoration among the Ona were their persons and their dance paraphernalia, while their patterns, like those of the Yahgan, ${ }^{3}$ were crude daubs of color, uncertain in line and simple in rhythm.

On the use of fur robes in the Chaco, Nordenskiöld ${ }^{4}$ writes that they are seemingly an impractical garment for a tropical climate infested with insects; but, as a matter of fact, the nights are often cool, while chilling winds sweep over the country in May and June. Formerly cloaks made of coypu-skins were common, but these have given way to sheep-skin robes owing to the trade value of the former, and the sheep-skin garments in turn are being replaced by capes or ponchos of woven material. Robes in the Chaco are worn fur side inivard, and they are painted on the skin side (fig. I2).

The Tehuelche cape (fig. I), known as quillango, is a fur robe measuring a few inches more than five feet on a side. The fur was worn next to the body and the skin side was elaborately painted.

\footnotetext{
${ }^{3}$ Lothrop, 1928, p1. ix.

${ }^{4}$ I919, p. 98.
} 
Around camp or at home in the toldo men kept this garment in place with their hands, but ahorse they wore a belt and slipped the cloak from the shoulders when they wished to liberate their arms (fig. 3). The women's robes were secured by a belt and by a pin inserted at the throat. From this fact it follows that the specimens here described were males' garments, for none of them exhibit pin marks.

In addition to the cape, Tehuelche men wore a loincloth of hide or of woven material, while the women had a small apron falling to the knees. Poth sexes wore tall boots made by stripping off entire the hocks of pumas or horses, which were sewn up at the bottom to form the toe. The women did not remove the hair from their boots, but the men did. In wet

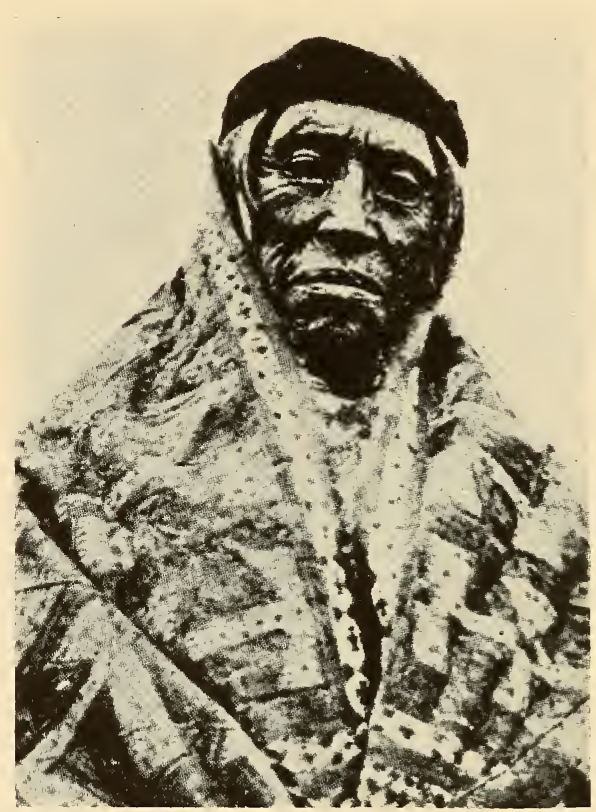

FIG. I.-Tehuelche Indian, showing cloak. (After Outes and Bruch) weather the Tehuelche covered these potro boots with what is described as an overshoe, but this we judge to have been the primitive Tehuelche footgear, corresponding in type to the moccasin of the Ona. ${ }^{5}$

Tehuelche painted robes could have been obtained in almost unlimited numbers until a few years ago, but not many of them have reached museums. The reason for this seems to be due to the fact that they were so common that no one took the trouble to preserve them, while, doubtless for the same reason, only short descriptions of their manufacture are on record. The five specimens on which this study is based were purchased by the writer for the Museum in I925 at Galliegos in southern Patagonia. Other examples may be seen in the Museo de la Plata, the American Museum of Natural

${ }^{5}$ Lothrop, I928, pp. 54-55. 
History, the United States National Museum, and the Peabody Museum of Harvard University.

In regard to the material preferred by the Tehuelche for their robes, Father Falkner ${ }^{6}$ writes :

Those made with the skins of young colts and mares are the least valuable. The mantles made of the skins of a small, stinking animal, like our polecat, which they call yaguane, are superior to these last. . . .

The fur of the coipu, or otter, is in equal esteem with that of the yaguane, or maikel. . . .

The mantles made of the skins of guanaco are in still greater estimation than those before-mentioned, on account of the warmth and fineness of their wool, and their long duration. But those which are in the highest esteem of all are made with the skins of small foxes, which are exceedingly soft and beautiful. They are of a mottled grey, with a red cast, but not so durable as those of the guanaco.

On this subject Musters ${ }^{7}$ writes :

Besides the guanaco mantles which are most generally worn, others are made from the skins of the fox, puma, wild cat, cavy, and skunk; the fur of the latter and of the wild cat being the most valuable, but like the others, are generally intended only for barter.

In addition, the present writer has seen several mantles of ostrichskins from Patagonia. While these have undoubtedly been made by the Indians and exhibit characteristic indigenous sewing, yet it is exceedingly doubtful that they were ever used locally. On the contrary, it appears that they were manufactured merely in order to trade with white settlers.

A considerable variety of furs, then, were used on occasion in Tehuelche robes, but in most cases the guanaco was selected. This wild relative of the llama, one of the four New World camels, has been most succinctly described by the friend of Capt. Musters ${ }^{8}$ who exclaimed that it combined "the neigh of a horse, the wool of a sheep, the neck of a camel, the feet of a deer, and the swiftness of the devil." We shall examine the methods of hunting guanaco and the weapons employed.

When first encountered by Europeans the Tehuelche armed themselves with bows and arrows. Their bows apparently were not like those of the Ona, for they are described as short and stiff. ${ }^{9}$ After

6 I774, p. I28.
${ }_{\text {I } 87 \text { I, p. I } 80 .}$
8 Ibid., p. I27.

${ }^{9}$ Oviedo, lib. xx, cap. vi. 
the introduction of the horse, between I670 and I74I, the Tehuelche abandoned their ancestral weapon in favor of the bolas. As pointed out by Outes, ${ }^{10}$ there is no literary mention of bolas in Patagonia before the expedition of John Byron in I764, but all travelers thereafter speak of it. On the other hand, various discoverers during the first half of the sixteenth century observed bolas in use among the inhabitants of the La Plata littoral, such as the Minuané, Charrúa, and Querandi, but archeological evidence indicates that this missile was never employed so extensively in that region as it was later in Patagonia. In Chile. Bolivia, and Peru occasional finds have been made of grooved stones suggesting bolas, but their use never was typical, for the inhabitants of these lands preferred the sling. The greatest development of the bolas, then, was among the Tehuelche, but the center of dispersion apparently was the La Plata district.

Among the Tehuelche three types of bolas were employed (fig. 2, $g-i)$. The simplest of these, known as the bola perdida, was a stone ball attached to a cord about a yard long. This was employed in warfare, for finishing off wounded game, and for killing puma, which they always attacked at close quarters (fig. 3). A second type, called chumé, had two balls joined by a cord six or seven feet long. This was intended primarily for capturing ostriches. A third type, with three balls, known as yachiko, was dedicated to the pursuit of guanaco.

In compound bolas one ball is especially designed to be grasped in the hand when the missile is spun and cast. We do not know the Tehuelche name for it, but it is called the manejo in Spanish. This stone is not round, but oval (fig. $2, d-f$ ), and is lighter by about a third than the other balls.

In former times bolas' balls were made of stone or hematite, but the Tehuelche have employed lead or copper when procurable. Archeological examples from southern Patagonia, illustrated in fig. $2, a-c$, show various types of grooving. More recently, however, the stones have been enclosed in leather sacks and therefore have no grooves. The average weight of a ball is perhaps a pound, but there is a good deal of variation in this respect.

The cord used in Tehuelche bolas is of ostrich or guanaco sinew, braicled four-ply.

As a weapon the bolas has both its advantages and disadvantages.

101905 , p. 427. 
The hunting range ahorse is up to seventy yards, which compares favorably with the effective bow-and-arrow hunting range. Its advantage over the arrow is that it will kill or entangle across a wide

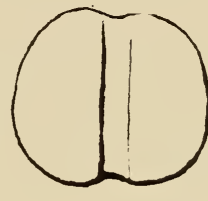

$a$

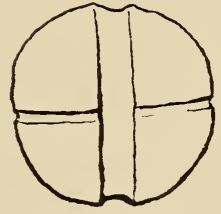

c

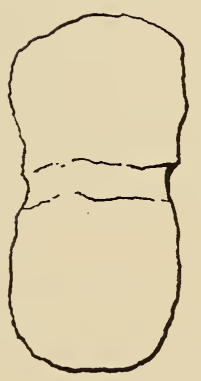

$e$
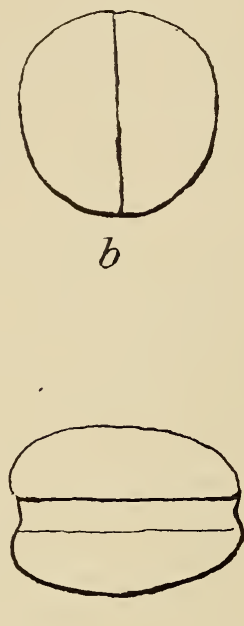

$d$

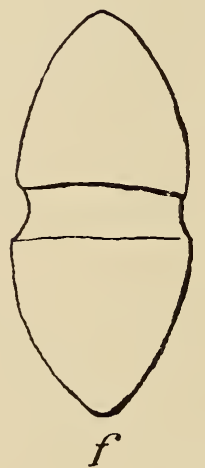

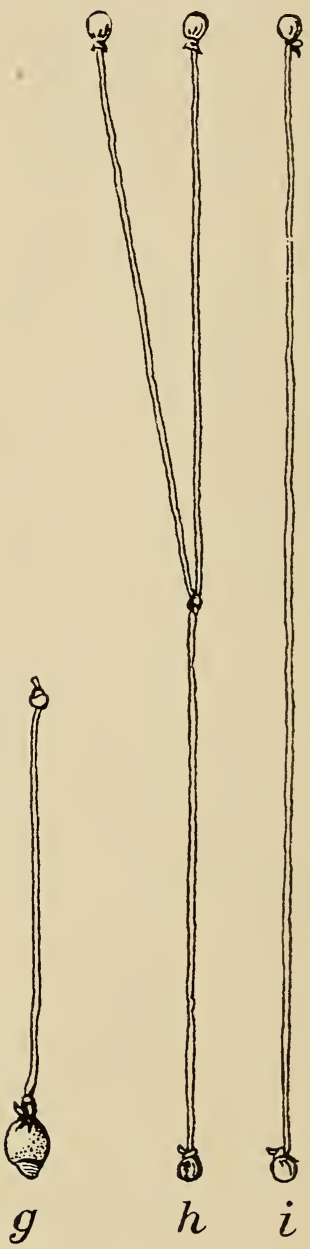

FIG. 2.-Tehuelche bolas. $a-f$, Río Galliegos valley (Hamilton collection; not to scale); $g-i$, after Musters.

path, while the arrow must make a direct hit. On the other hand. the release of the arrow can be timed exactly, so that it is possible, by gatuing the speed, to strike a transversely moving target; but it is impossible to time so accurately the swing of the bolas, and the 


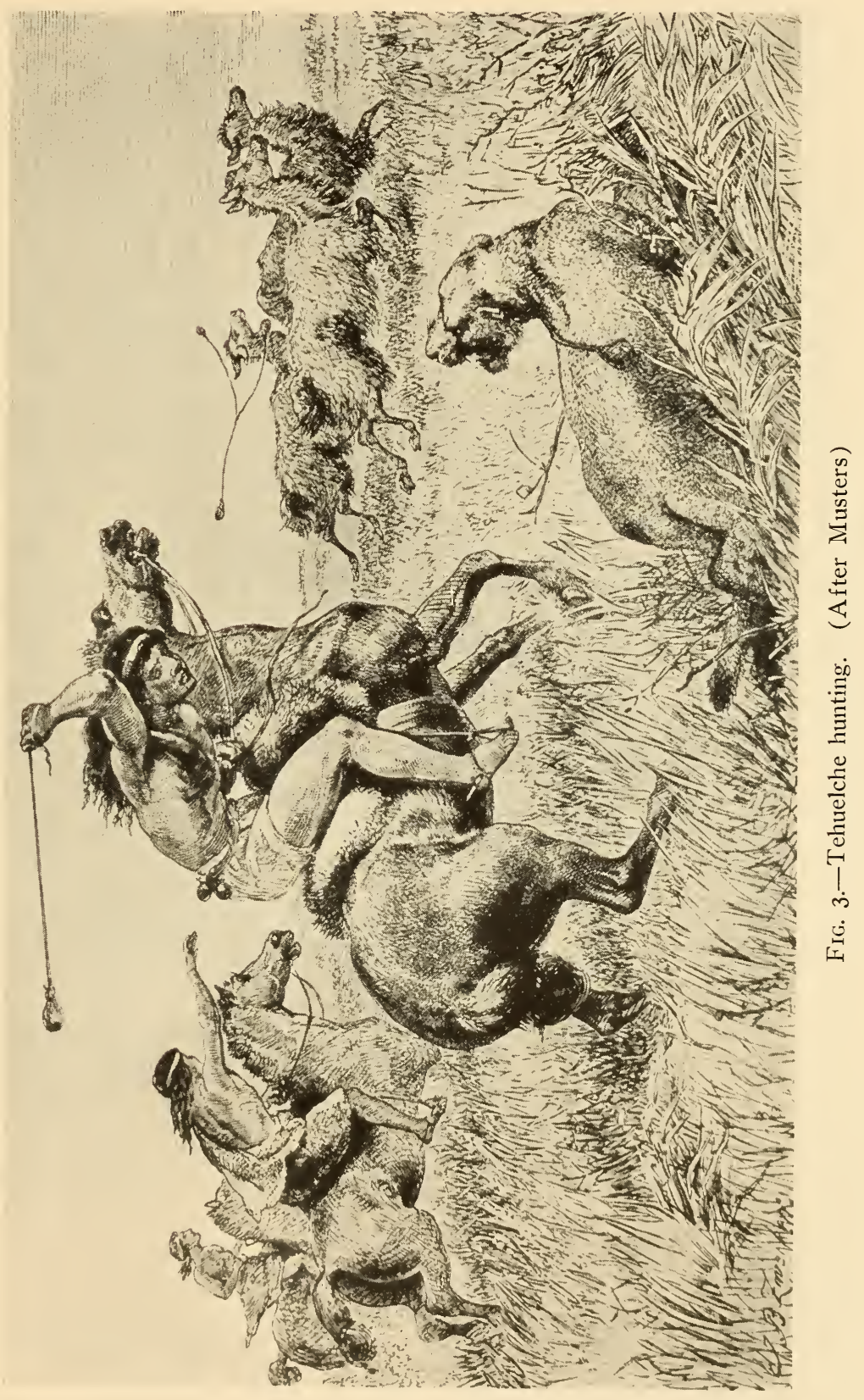


hunter must be moving in the same line as the quarry when he makes his cast.

The actual hunting of guanaco was a joint occupation for all male members of the group who happened to be living together. After camp had been broken, the horses packed, and the women and children set on the road, the men would sit around a fire and smoke for a while. Then, at the command of the chief, "two men start off at a gallop and ride around a certain area of the country, varying according to the number of the party, lighting fires at intervals to mark their track. After the lapse of a few minutes two others are dispatched, and so on until only a few are left with the cacique. These spread themselves out in a crescent, closing in and narrowing the circle on a point where those first started have by this time arrived. The crescent rests on a baseline formed by the slowly-proceeding line of women, children, and baggage-horses. The ostriches and herds of guanaco run from the advancing party, but are checked by the pointsmen, and when the circle is well closed in are attacked with the bolas, two men frequently chasing the same animal from different sides. The dogs also assist in the chase, but the Indians are so quick and expert with the bolas that unless their horses are tired, or they happen to have gambled away their bolas, the dogs are not much called into use." 11

Information about the manufacture and decoration of guanaco robes is scanty. The therefore quote in full the accounts of Musters ${ }^{12}$ and Bourne, ${ }^{13}$ as they are the most extensive we have been able to find. ${ }^{14}$ Musters' narrative follows.

The skins are first dried in the sun, being pegged down with thorns of the algarroba tree. When dry they are taken up, and scraped with pieces of flint, agate, obsidian, or sometimes glass, fixed in a branch naturally bent so as to form a handle [fig. 4]. They are then smeared over with grease and liver kneaded into a pulp. after which they are softened in the

\footnotetext{
11 Musters, I8 7 I, p. $7 \mathrm{I}$.

12 Ibid., pp. I79-I80.

13 I853, pp. 98-99.

1+ Cooper (1925) cites the following references to Tehuelche robes and colors: Maximilianus Transylvanus, I523, p. Av. Ladrillero, I880, p. 498. Nuño da Silva, I906, p. I35. Outes, 1905, p. 258. Pigafetta, I906, I, pp. 48-49. Oviedo, II, p. 43. Fletcher, I854, p. 53. Spegazzini, I884, p. 234. Dr. Cooper has most kindly assured me that he knows no detailed accounts except those of Bourne and Musters.
} 
hand until quite pliable, when they are placed on the ground and cut with a small, very sharp knife [fig. 5] into pieces, dovetailed so as to fit one into the other [fig. 6], in order to secure strength of seam, and parcelled out amongst a party of four or six women, with corresponding quantity of needles and thread, consisting of bodkins formed out of sharpened nails, and dried sinews from the back of the adult guanaco. A whole mantle is never sewn together at once, but when half is finished it is pegged out and the paint applied to it thus. The surface is slightly damped, and each woman takes a cake or piece of red ochre, if the ground is to be red, and, keeping it damp, lays the paint on with great care. When the ground is finished, the pattern of small black spots and blue and yellow lines is painted with the greatest exactness, the women working all day with the most assiduous industry. When completed it is left for a night to dry, and the other half and wings which serve in lieu of sleeves, are duly completed, and subsequently all are joined together, presenting, when finished, an unbroken surface of fur. The favorite pattern (except when the wearer is in mourning) is a red ground with small black crosses and blue and

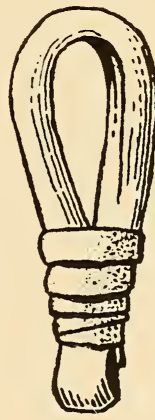

F I G. 4.Tehue l che fl e s h e r. (After Outes and Bruch) yellow longitudinal lines for borders, or a zigzag of white, blue, and red. The untiring energy with which the women work, and the rapidity with which they sew are astonishing. When a man is married, his wife, or wives, of course manufacture his mantles, assisted by their friends, whom they help in their turn; but should he be a bachelor, as in my unfortunate case, he gives out his skins to a fair lady, who works like other people I have heard of-on half-profits, and the hunter generally loses by the bargain; at least such was my experience, some thirty or forty skins only producing a mantle containing about a third of their number.

Bourne's account of mantle-making differs in detail from that of Musters, so we quote it also in full.

The skins of young guanacos are selected for mantles, on account of the superior fineness and softness of the hair. Nearly a dozen skins are used for a single mantle, as a large part of each is esteemed unfit for use. and thrown away. The skins, while green, are stretched to their utmost tension on the ground to dry. When partially dried, they are scraped on the inside with a stone sharpened like a gun-flint, sprinkled the while with water, to facilitate the operation. When the surface is made tolerably smooth, and of a pretty uniform thickness, it is actively scoured with a coarse-grained stone, till it has a bright polish. When the skin is again dried, then crumpled and twisted in the hands till it becomes perfectly soft and pliable. The thread, as has been stated, is made from the sinews of 
the ostrich. They are extracted by the exertion of great strength, and divided into strings about the size of an ordinary shoe-thread. They are then twisted, the ends are scraped to a point, and when dry become stiff; they are now ready for use.

Two pieces of skin are cut to fit each other. The tailoress (for all the work, from the curing of the skins to the last results, is done by the squaws) holds the edges together with the left hand, and drills them for sewing with a sharpened nail, held between the first two fingers of the right hand; the pointed thread, held between the finger and thumb, is inserted and drawn through, and so the work goes on. The stitches are tolerably fine, and a very neat seam is made. Other pieces are added, and when the whole is finished the seams are rubbed smooth with a bone. The fur being worn inside, there remains the work of outside decoration. With a due quantity of clay, blood, charcoal and grease, amalgamated for the purpose, the artist arms herself with a stick for a brush, and executes divers figures in black, on a red ground; which, if intended to show forth men, require a vigorous imagination to detect the purpose. They might pass for unhappy ghosts (if a little more ethereal in composition), or for deformed trees. They bear a rude resemblance to a chair in profile, or a figure 4; and are thickly disposed over the whole surface, in the attitude sometimes vulgarly termed "spoon-fashion." The garments are now complete; the edges are carefully trimmed with a knife, and the fabric is thrown over the shoulders, with the infallible certainty of fitting as closely as the native taste requires. ...

Certain comments may be made on the two descriptions of robemaking just quoted. In the first place, the tools enumerated are well known archeologically, and most of them have been illustrated by Outes (1905). Scrapers sometimes were hafted by setting them transversely in a block of wood and securing them with resin. ${ }^{15}$ More often the handle consisted of a split sapling, bent until the ends met, with the blade secured between them by lashings (fig. 4). Snub-nose scrapers, intended for use without hafting, are found throughout Patagonia, but not in great quantities.

Knife-blades are found all over Patagonia. However, the series we illustrate in fig. $5, a-d$, come from the region where the cloaks here described were obtained. Of these $b$ is a single triangular flake, retouched along the edges; $a$ is a symmetrical elongate blade which

15 Outes (1905, p. 339) states that this hafting is of Araucanian origin, taken over by the Tehuelche. The use of transversely hafted scrapers by the Ona of Tierra del Fuego, however, suggests that the culture transference may have been from the Tehuelche to the Araucanians. 
has been worked all over; $c$ is a lanceolate blade, again worked all over. While not rare, none of these forms is common. An apparently unique knife is seen in $d$-a form probably derived from some European prototype. The great majority of blades (fig. 5,

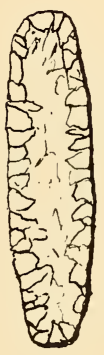

$a$

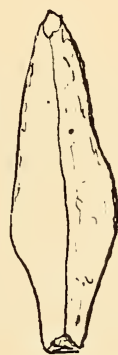

b

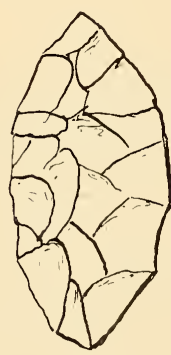

c

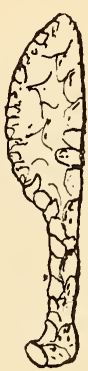

d

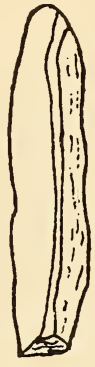

$e$

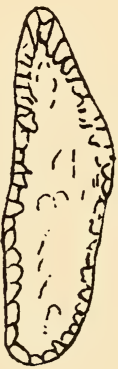

$f$

FIG. 5.-Tehuelche knife-blades. $a-d$, Río Galliegos basin (Hamilton collection); $e$, Gulf of San Jorge; $f$, Sierras Coloradas (after Outes)

$e, f)$ are of somewhat irregular shape, sometimes one- and sometimes two-edged, in type merging imperceptibly into the scraper class. On the Tehuelche manner of hafting stone knife-blades we have no information.

Bourne's account of preparing skins describes the scouring of hides with a coarse-grained stone. In the John Hamilton collection at Galliegos, which we had the privilege of inspecting, were a number of accurately cut rectangular blocks of porous lava about six inches long by two to three inches wide and thick, which might well have been used for this purpose. Outes ${ }^{16}$ describes and illustrates stone discs about three inches in diameter and an inch in thickness which may have been similarly employed.

Tehuelche " needles," used in the sewing, were not true needles with an eye, but simply awls. As among most primitive people, formerly they were of bone, particularly the leg-bones of birds, but in recent years the Tehuelche have used a nail or some piece of scrapiron.

As for the pigments employed to decorate Tehuelche cloaks, they were applied mixed with blood or with grease to a slightly dampened surface. Musters ${ }^{17}$ writes that the grease was obtained from the

\footnotetext{
16 I905, figs. I94, I95.

17 I 87 I, p. I72.
} 
scum of boiled marrow-bones, and he states that red paint was ocher, black paint an earth, and white paint a gypsum. Bourne ${ }^{18}$ says that black was obtained from charcoal, as was the practice among both Foot and Canoe Indians in Tierra del Fuego. No information is available about yellow, blue, and green pigments. We suspect that the green is always of European origin and has replaced blue, frequently mentioned by early travelers but not found on the Museum's specimens, which, by the way, illustrate the use of both native and European pigments. On the methods of applying paints, we have the statement of Bourne that a stick was used for a brush. The Tehuelche made small hair-brushes by binding together a bundle of slender roots, ${ }^{19}$ but apparently never used paint brushes. However, it must be remembered that a stick makes a good brush if the pulp has been removed by chewing so that a fibrous end remains. ${ }^{19 a}$ Certainly Tehuelche patterns have been applied with a neatness and precision perhaps not fully appreciable on existing specimens because the colors have run in the rain. ${ }^{20}$

Assemblage of skins we illustrate in fig. 6. This mantle contains twelve skins, placed alternately head to foot, as will be seen if the picture is reversed. From side to side there are five complete rows, two head-up and three head-down, while the sides contain skins which have been split into halves longitudinally. The result of thus piecing together the skins is an alternation of color, the white bellies and the café au lait backs of the guanaco succeeding each other in turn. Such robes have considerable commercial value today, and we have been told that more than half a million guanaco-skins were shipped from Patagonia in 1924.

Coming now to an examination of the painted patterns, preliminary inspection shows that the decorated surface habitually is divided into

\footnotetext{
18 Ubi supra.

19 One of these is illustrated by Outes and Bruch, fig. II 8 .

19a See Orchard, W. C., Fine-line Decoration of Southwestern Pottery, Indian Notes, vol. II, no. I, 1925.

20 The colors in pls. LXv and LXvi have been made more intense than on the weather-stained original specimens. The following color-scheme is employed in our line-drawings.
}

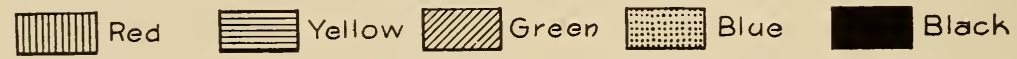


six fixed and limited portions, each of which is separately adorned in its own fashion. These divisions follow.

I. Edgc.-A strip of solid color runs completely around the entire edge of the robe. On the Museum specimens this is red in four cases and green in one.

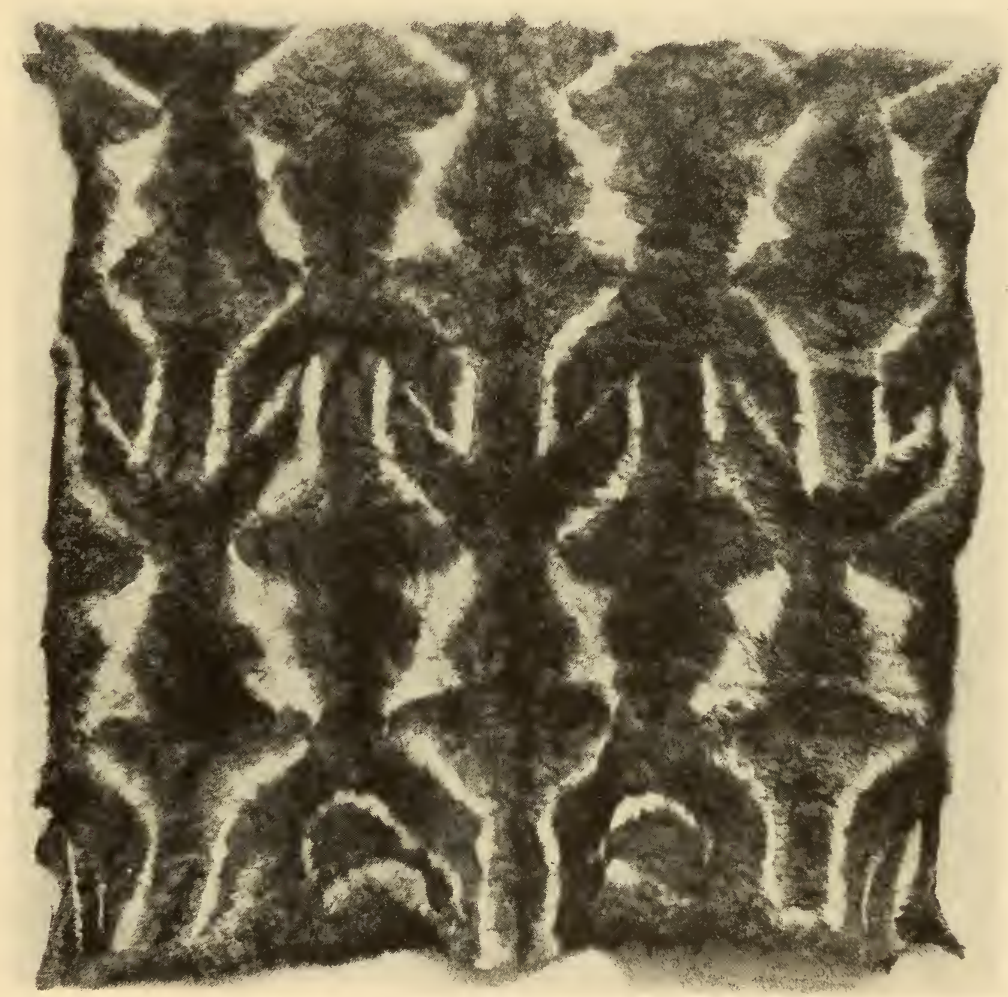

FIG. 6.-Fur side of a Tehuelche guanaco robe. Size, 61 x 63 in. (13/9769)

2. Onc-border pattern.-Along one border, next to the colored edge, is a band of polychrome motives set between black border-lines (fig. $7, a$ ).

3. Corner patterns. - At each end of the one-border pattern, at the corners of the robe come two identical designs (fig. $7, b, b$ ). These each are painted on a single piece of skin about a foot long, and they are wider than the one-border pattern. 
4. Corner tabs.-Just around the corners from the corner patterns are a pair of tabs painted in solid color (fig. $7, e, e$ ). They project slightly beyond the straight side of the robe. Nusters speaks of these as "wings."

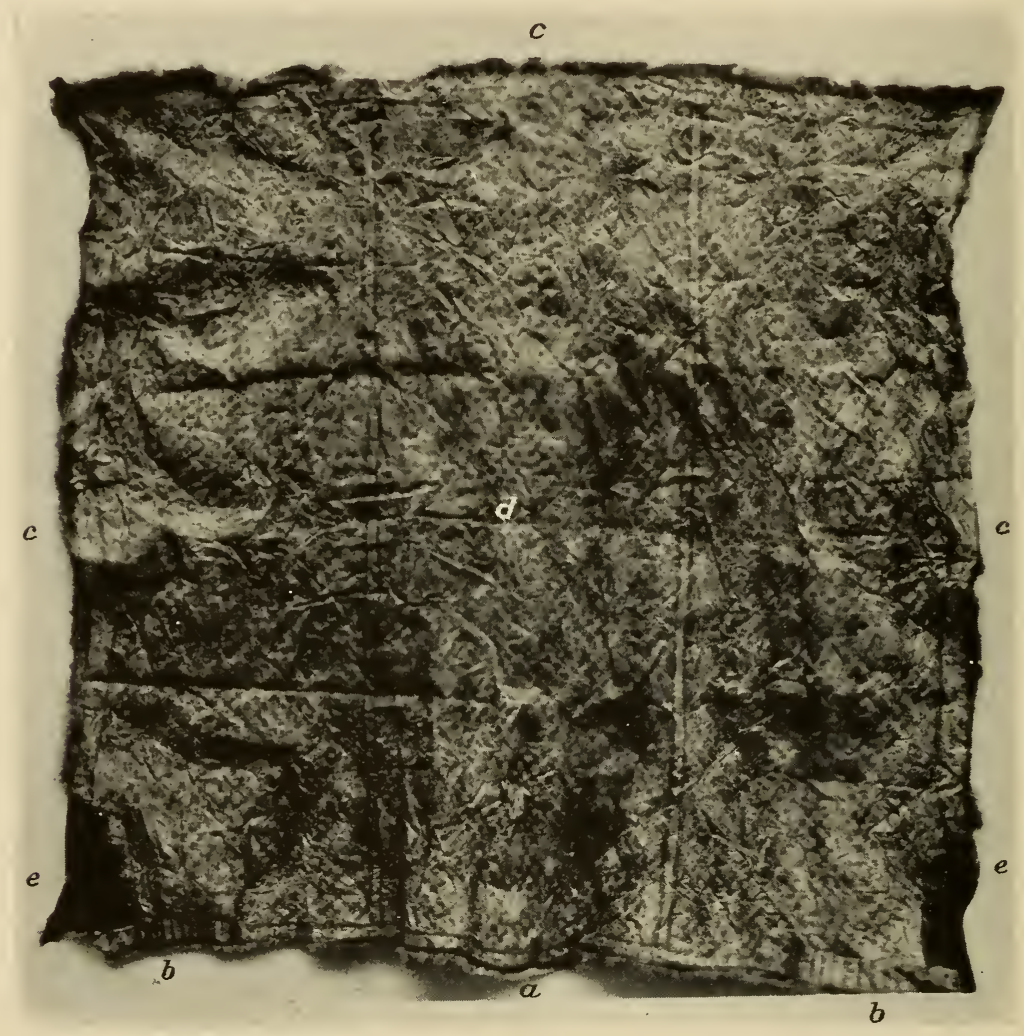

FIG. 7.-Skin side of a Tehuelche guanaco robe, showing distribution of patterns. (13/9769)

5. Three-border pattern.-Starting at the corner tabs, a polychrome design encompasses the three remaining sides of the robe (fig. $7, c, c, c$ ). Like the one-border pattern, this is placed between black lines, but it is a little wider, though not so broad as the corner motives.

6. Central field.-Inside the patterns we have described, the remainder of the cloak is either painted in solid color or is completely 
covered with polychrome decoration. Of the Museum specimens, one is painted green all over (fig. $9, a-c$ ), while another is red $(d-f)$. It will be noted that in both cases the edge of the robe has a contrasting color. The remaining examples here illustrated have the central field completely covered with rather elaborate polychrome motives, which are segregated in three panels by two dividing bands, as seen in fig. $7, d$.

As the robe is actually worn (fig. I), the one-border pattern runs across the back and over the shoulders. This brings the corner patterns and corner tabs over the arms, so that roughly they suggest the sleeves and cuffs of a coat. The three-border pattern extends down the front edges and across the bottom.

The patterns themselves consist of extremely simple elements, such as the square, diamond, triangle, and cross, but these are worked into combinations surprisingly complex in view of the cultural poverty of the Tehuelche in general. This complexity arises not only from varied juxtaposition of design elements, but also from the alternation of colors.

One of the favorite border motives is a checkerboard pattern based on three colors, of which one is the natural hide. These patterns are so arranged that successive squares form diagonals or zigzags. Examples of the diagonals are illustrated in fig. 9, $e$; pls. Lxv, $c$, and Lxvi, $a$; while zigzags appear in fig. 9, $a, f$, and pl! Lxv, $b$. In each case the zigzags enclose triangles of contrasting color.

Diamond motives are also common. Usually they are boldly drawn, as in figs. 8, $a$, and 9, $c, d$, and pl. Lxvi, $b$. In one case, fig. 9. $b$, crossed diagonal lines form small diamonds which have been filled with color in the fashion of a checkerboard pattern.

The triangle commonly is a minor pattern employed as a space-filler, as in fig. 8, a. c, and 9, $c$. In fig. 8, $b$, and pl. Lxvi, $b$, however, it occupies a major position in the design.

Central patterns are painted on a larger scale than those on the corners and borders, from which they also differ because the colors stand by themselves, while in corner and border motives colors are used to fill black-outlined designs. Central patterns either are like the large meanders seen in fig. I or are based on square and cross in various combinations. In fig. $8, d$, there are shown four-color alternating groups of four and five squares connected by diagonal lines. 
Pl. Lxv, $d$; has a much simpler assemblage of alternating squares set between parallel lines of red. Pl. Lxy has the most complicated pattern of the Museum collection, for it contains a four-unit design built up of crosses flanked on all sides by squares.

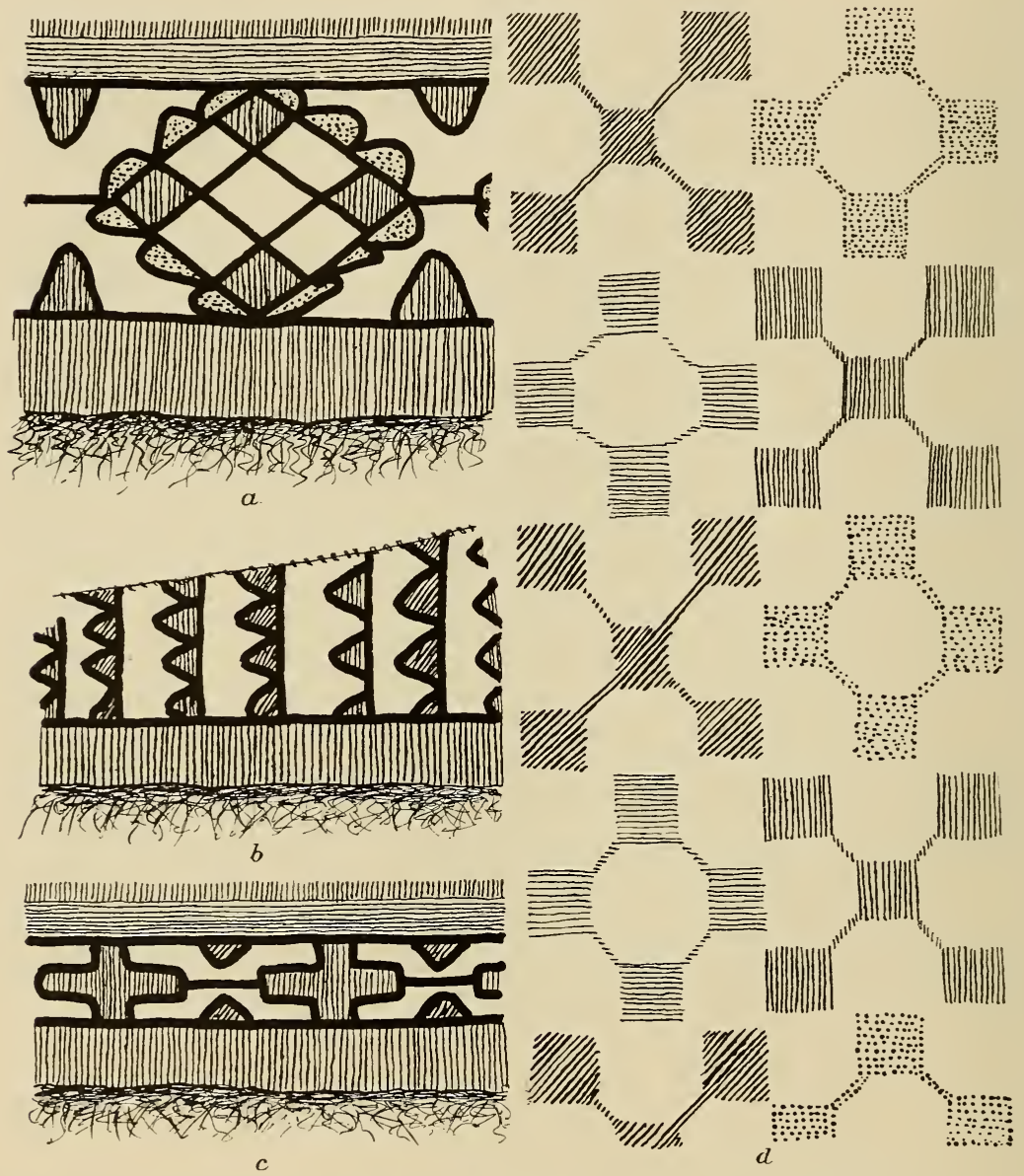

FIg. 8.-Designs from a Tehuelche guanaco robe. $a$, Three-border pattern; $b$, corner ; $c$, one-border pattern; $d_{n}$, center. (13/9;69)

Such, then, are the Tehuelche patterns. To what are they related and where do they belong in the cultural scheme of southern South America? Te have already pointed out that the central patterns exhibit a different tradition from the border and corner patterns. The 
latter consist of black outlines filled with color, a decorative method particularly characteristic of New World pottery. Furthermore, the confinement of design within bands is a pottery characteristic, while

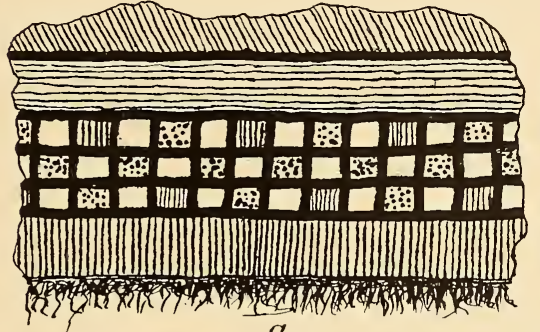

a

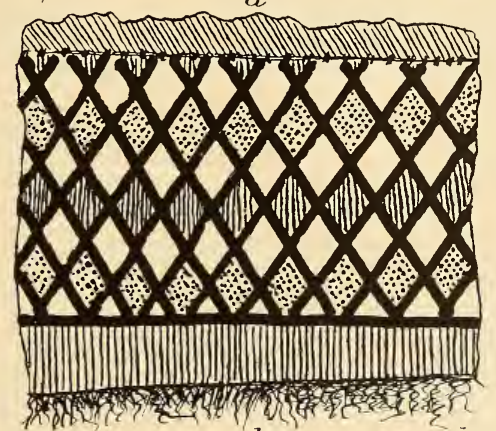

$b$

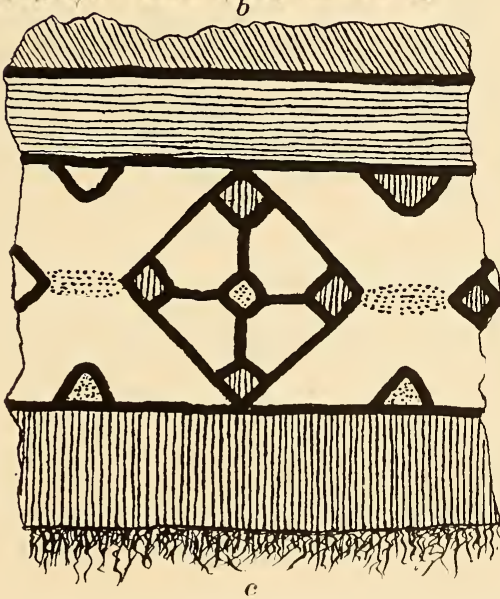

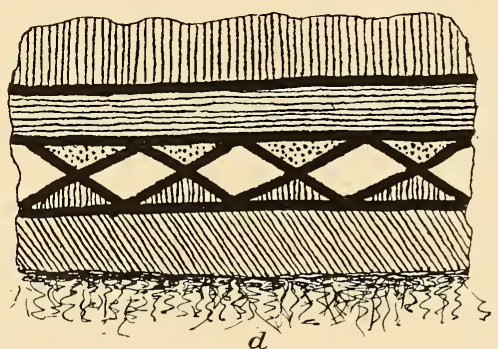

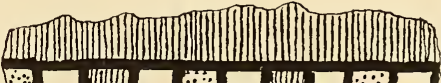

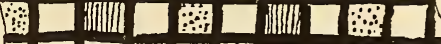

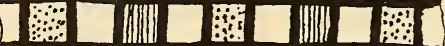

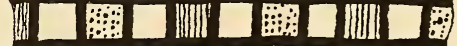

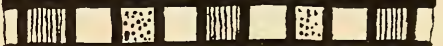

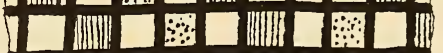
(10)
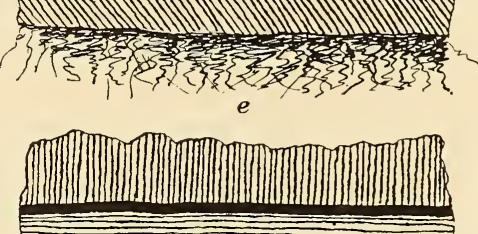

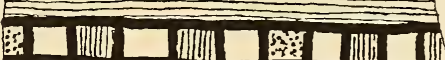

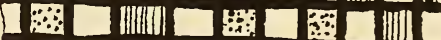

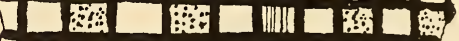

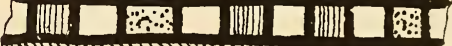

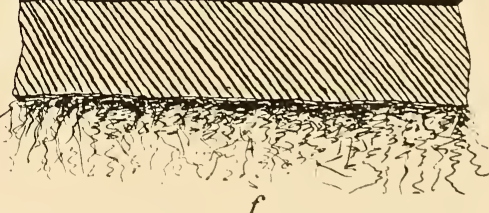

FIG. 9--Tehuelche patterns. $a, d$, One-border patterns; $b, c$, corner patterns; $c, f$, three-border patterns. (a-c, 13/9770; $d-f, 13 / 9767)$

some of the patterns themselves, such as fig. 8, $a-c$, or pl. Lirr, $c$, strongly suggest widespread ceramic motives. Hence to seek comparisons we turn first to ceramic remains. 
The painted pottery found nerest to the Tehuelche comes (I) from the coastal region in Chile between Valparaiso and Puerto Montt, (2) from the Calchaquí region in northwestern Argentina, (3) from the Gran Chaco, (4) from the south bank of the Río Luján, and (5) from the islands of the Paraná delta. The Chilean pottery is represented by a few examples in the Museum from Temuco in the province of Cautín, and we have seen also a small collection in the National Museum at Santiago. It is a grayish white ware with black or red designs strongly recalling ceramic remains from our Southwestern states. The patterns afford no ground for comparison with those of the Tehuelche.

Calchaquí pottery exhibits within itself wide variations which we have not space here to discuss. In glancing through museum collections and printed illustrations we have encountered sufficient likeness to Tehuelche art to arouse a feeling that there is some vague relationship, especially with specimens from the province of Mendoza. For instance, from Huasan ${ }^{21}$ and many other sites come painted checkerboard designs suggesting Tehuelche art. However, we know little of chronological sequence in the Calchaquí, and it would be unwise to draw conclusion on this or similar evidence which might be presented.

Modern pottery from the Gran Chaco does not suggest to the writer interrelationship with the Tehuelche.

On the south bank of the Río Luján formerly lived the Querandí Indians who attacked and fired the first settlement at Buenos Aires. This tribe has totally disappeared and the only trace of them today consists of archeological remains. A presumably Querandí site on the Arroyo Sarandí, excavated in 1925 by the Thea Heye - La Plata Expedition, yielded both incised and painted pottery. The latter showed no relationship to Tehuelche art, but the incised ware suggests Tehuelche meander patterns, seen in fig. I.

Painted pottery from the delta islands of the Paraná presumably is the handiwork of Guarani Indians. A site on the Arroyo Guayracá (Arroyo Malo), excavated by the Thea Heye - La Plata expedition, produced a few vessels decorated with red and black paint. As might be expected of Guarani ceramics, however, the designs point definitely to the north and show no relationship with Tehuelche art.

\footnotetext{
${ }^{21}$ Lafone Quevedo, 1905.
} 
A survey of painted pottery in relation to Tehuelche border and corner patterns then yields no very definite connections, although the Tehuelche designs considered suggest in themselves a pottery technique. An examination of basketry decoration from the coast of Chile, from the Araucanian district, and from the Gran Chaco, gives only negative results. At the same time, some of the Tehuelche patterns, especially those in the central field, indicate a basketry prototype.

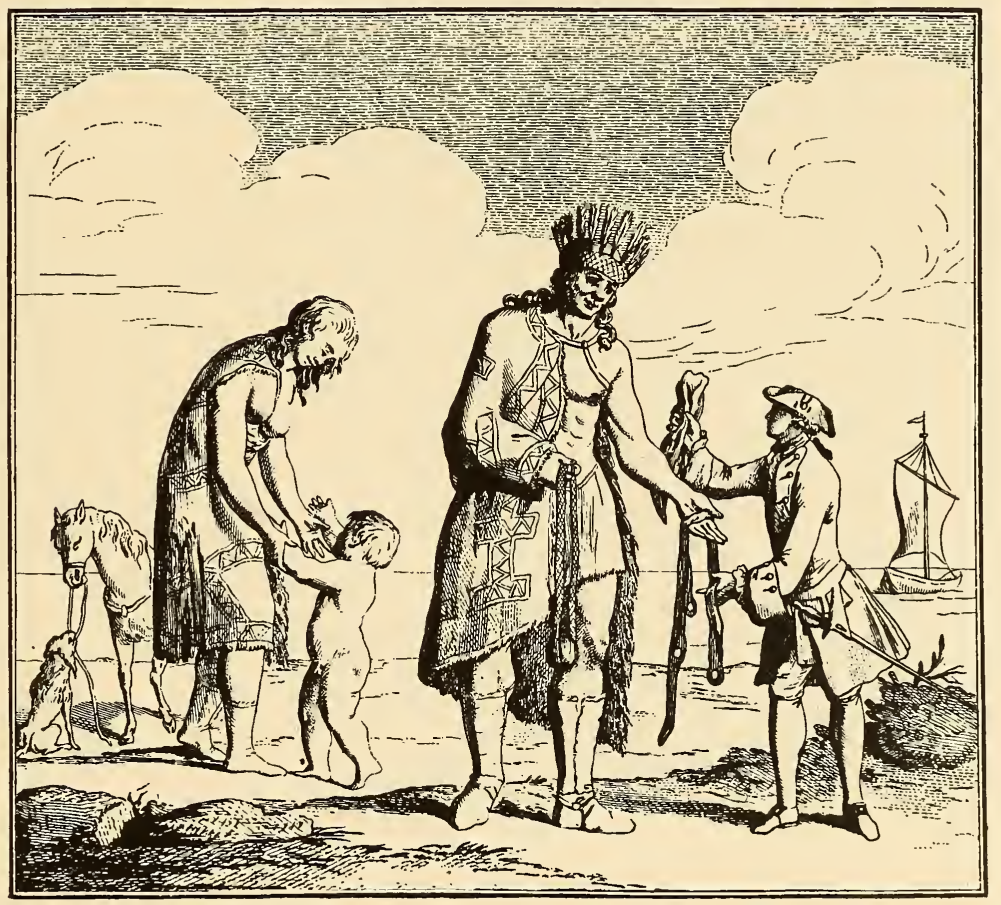

FIG. I0.-Tehuelche Indians. (After Pernetty)

Araucanian weaving, ${ }^{21 a}$ on the other hand, has certain definite links with Tehuelche robes. In the first place, checkerboard patterns are common and often are arranged to form zigzags. Secondly, when the Araucanian poncho has a border pattern, it is not a unit completely encircling the cloth, as is the case with Bolivian and Peruvian textiles. On the contrary, the border designs are arranged in opposing pairs, which differ from each other in color, pattern, and

21a Looser, 1927. 
width. While this ordering of border decoration is not exactly like the Tehuelche arrangement, it is the only suggestion of it that we have been able to find in contiguous territory.

The guanaco robe illustrated in fig. I has for its central pattern a series of large meanders and frets, quite different in character from the corresponding designs on the Museum's specimens and on others examined by the writer. We believe this represents an older current

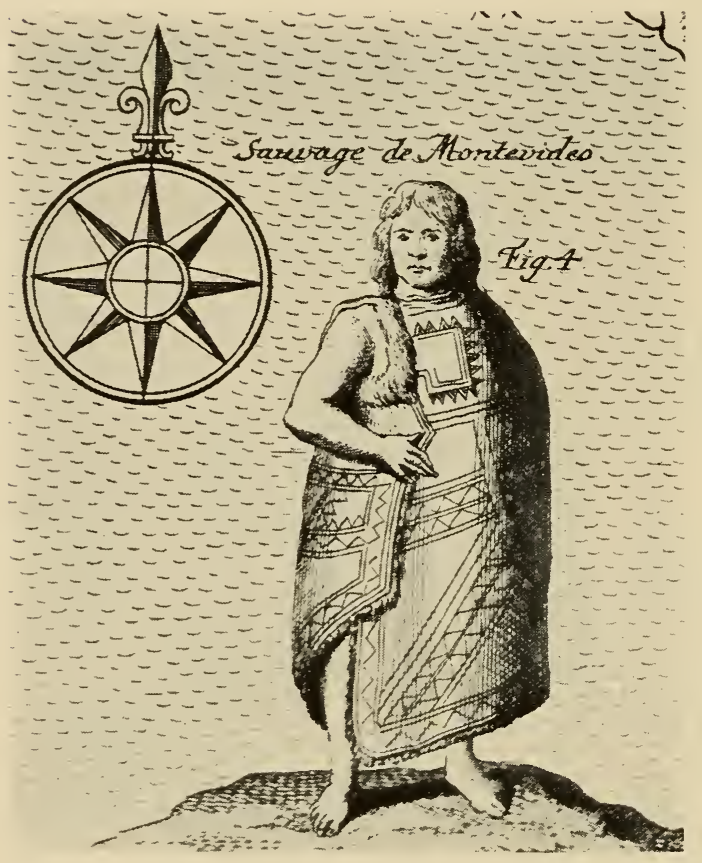

FIG. II.-Charrúa Indian. (After Pernetty) of Patagonian art. In fig. Io we reproduce an eighteenthcentury picture of Patagonian robes showing the decorations, probably drawn with some accuracy, as the artist must have had an opportunity to inspect the specimens b r o ught back to Paris by the expedition of Duclos-Guyot. ${ }^{22}$ The type of design depicted corresponds with verbal descriptions of contemporary and more recent date. For instance, d'Orbigny speaks of " un manteau de peaux d'animaux. sur lequel, du coté opposé au poil, ils figurent des greques irregulieres et variées," ${ }^{23}$ while the description in Pernetty states that the robes were painted with blue and red figures "qui semblent approcher des caracteres Chinois, mais presque tous semblables, \& séparés par des lignes droites, qui forment des especes des quarrés \& des lozanges." The description of MIusters, already quoted, implies that there were at

22 Pernetty, vol. II, p. I25, footnote $b$.

$23 \mathrm{Vol}$. II, p. 22. 
the time of his journey two distinct classes of design, and of these one was marked by zigzags like the robe in fig. Io.

In fig. I I we illustrate a cloak from Montevideo adorned in much the same fashion as ancient Patagonian specimens. This piece must have been made by the Charrúa Indians, who formerly inhabited the western half of Uruguay, for Pernetty ${ }^{24}$ expressly states that it was worn by natives who lived only a few leagues from the city. In describing these garments he says that they were " peint en rouge

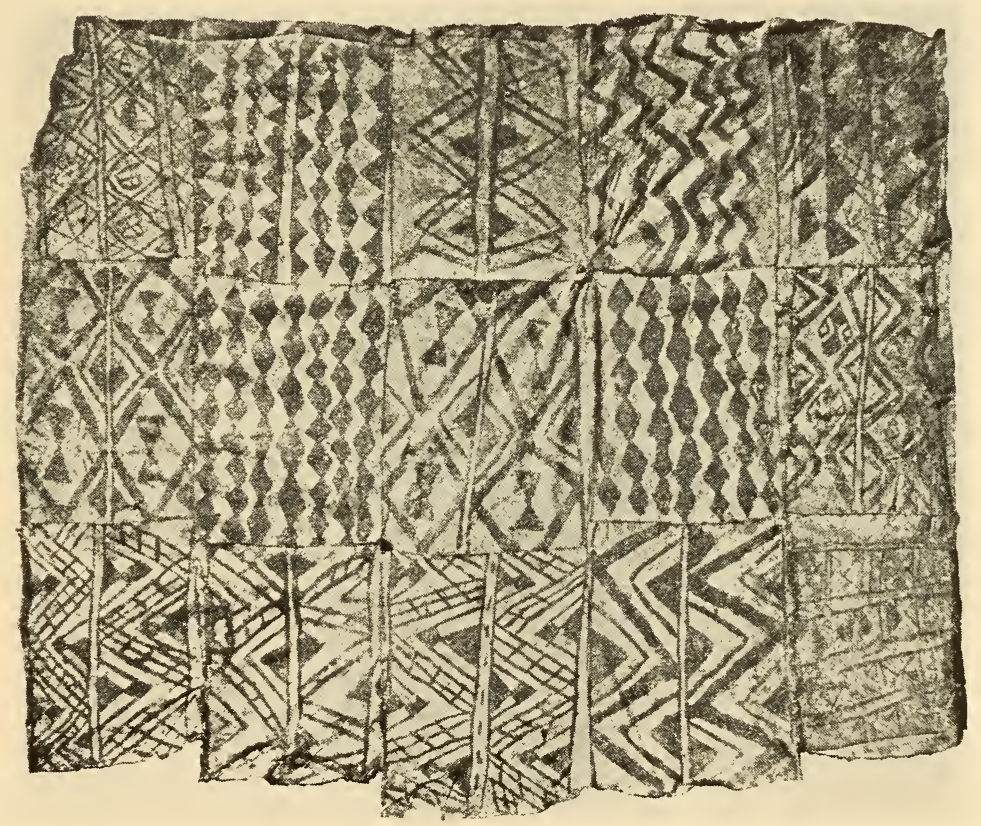

FIG. I2.-Otter-skin robe. Mataco Indian. (After Nordenskiöld, I903)

\& en bleu gris, par. quarrés, lozanges \& triangles." The Charrúa Indians have been extinct for many years, and no examples of their perishable handiwork probably are in existence, but the engraving has been executed with such detail that we can feel confidence in its accuracy.

The ancient school of design depicted in figs. ro and Ir has survived to this day among tribes of the Gran Chaco, not in the

${ }^{24}$ Op. cit., vol. I, p. 296. 
weaving but in painted robes, carved gourds. and facial painting. In fig. I2 we show an otter-skin robe made by the Mataco Indians. Each of the fifteen skins in this garment has been decorated with its own individual pattern, painted in two distinct manners, which perhaps indicates that two individuals coöperated in its manufacture. At any rate, the thin-line designs are based on a series of squares, lozenges, and zigzags obviously suggestive of old-time decorations of the Charrúa and Tehuelche.

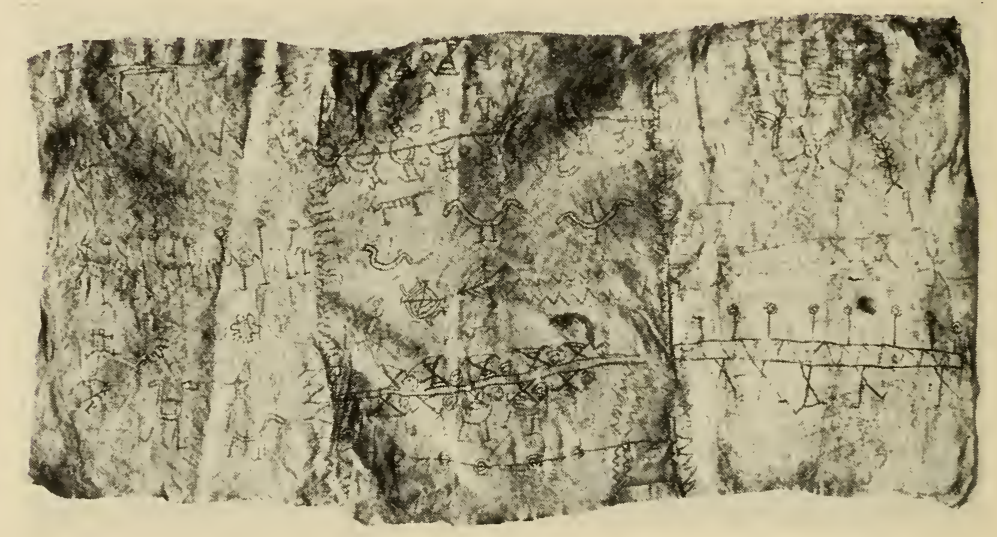

FIG. I3.-Skirt with painted decoration. Lengua Indian. Length, 57 in. $(14 / 600)$

Skin robes, as already stated, were in general use throughout the Chaco until recently. They embraced the kind seen in fig. I2, marked by geometric decoration, and also a second class, painted with crude life forms (fig. 13). The second group apparently is totally unrelated to Tehuelche mantles, on which zoömorphic patterns are completely absent, but this type of design is ancient, for it reflects pictographs found in the Chaco and farther to the west and south.

Incised or burned designs on gourds are common throughout the Chaco, ${ }^{25}$ and these patterns at times suggest early Tehuelche motives. Similarly facial painting also recalls the art found farther to the south. ${ }^{26}$

${ }_{25}$ The technology and distribution have been discussed by Nordenskiöld, I919, pp. 222-230.

${ }^{26}$ Lehmann-Nitsche, I904. 
What we have called the ancient Tehuelche school of design has archeological affiliations over a very wide area. Nordenskiöld ${ }^{27}$ published the Mataco robe reproduced in our fig. I2 because he recognized a connection with designs on incised pottery excavated near the San Francisco, a tributary of the Bermejo river. Incised pottery with patterns exhibiting local variations but in general recalling Tehuelche designs is found along the course of the Paraná river (fig. I4), especially in the provinces of Santa Fé, Entre Ríos, and
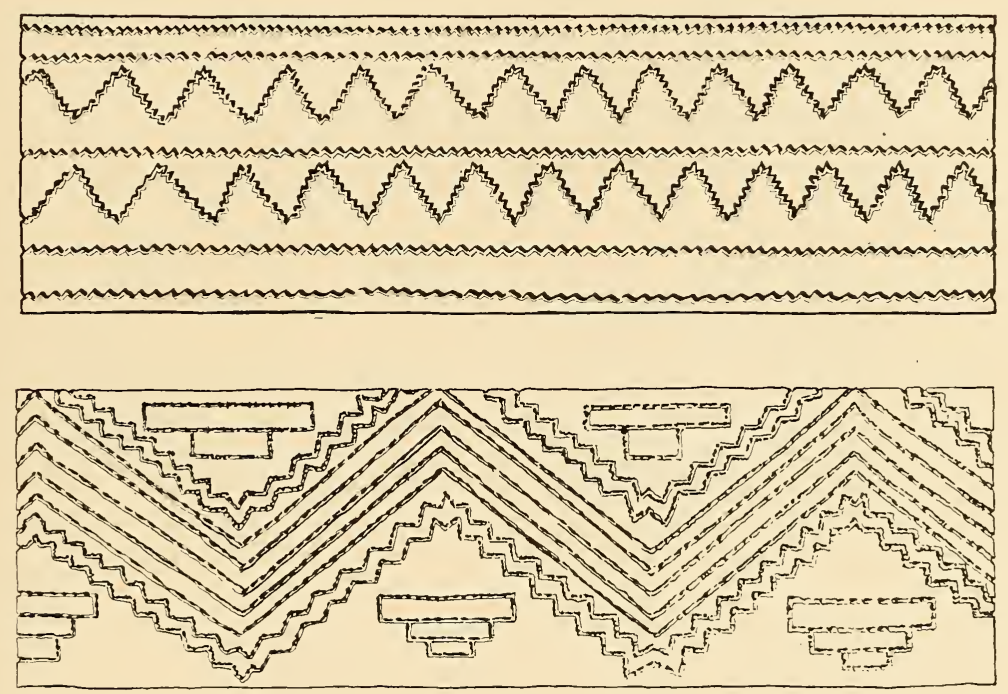

FIG. I4--Designs incised on pottery vessels. E1 Cerrillo, Paraná Guazú river, Argentina. (14/7II7)

Buenos Aires. This incised ware indeed extends southward along the Atlantic littoral ${ }^{27 a}$ into Patagonia well beyond the Deseado river, that is, to south latitude $48^{\circ} .{ }^{28}$ Burial grounds and refuse heaps in the Paraná delta yield comparable designis scratched on bone and antler objects. ${ }^{29}$ Incised decoration on pottery from northwestern

\footnotetext{
$2 \pi$ 1903, fig. I3.

$2 \pi a$ See Outes (1908) and Holmes (I9I2).

${ }^{28}$ Incised designs from Patagonia have been published by Outes, I904. This important archeological paper, as well as historical sources from Pigafetta to d'Orbigny, have not been utilized in distributional maps published by Spinden and Wissler, for they draw the southern limits of pottery at the Rio Negro.

29. Torres, I9II.
} 
Argentina, especially from the province of Mendoza, ${ }^{30}$ at times is strikingly like Tehuelche motives.

Aside from fur robes, the most elaborately decorated objects from Patagonia are ceremonial axes, plaques, and labrets, and, as might be expected, the patterns on them show the closest resemblance to the old-style embellishment on skin. ${ }^{31}$ In fig. I 5 we illustrate a stone

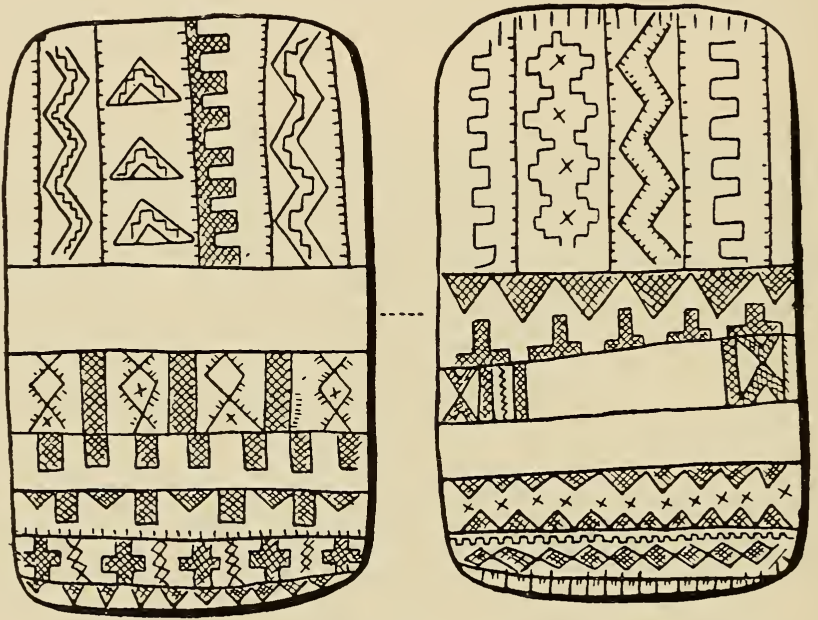

FIG. I5.-Engraved stone plaque. (After Outes, I9I6)

plaque engraved with fine-line designs, unusual though not unique in their elaboration. These consist of triangles, lozenges, zigzags, and meanders, executed in a manner very suggestive of the cloak in fig. Io, as well as some of the recent border patterns. The purpose of the engraved axes and plaques has been the subject of controversy, but there can be little doubt that they have an antiquity of several centuries.

Our survey of Tehuelche robes has shown that this kind of garment once was in general use throughout southern South America.

${ }^{30}$ For example, the Chaquiago incised ware, published by Lafone Quevedo, I905.

31 Axes and plaques have been illustrated by Ambrosetti (I901, 1902, 1904), Giglioli (I903), Holmes (I912), Lehmann-Nitsche (I909, I909a, I916), Outes (1905, I908, I916, I916a), Verneau (1903), and Verneau and Vaulx (1902). Lehmann-Nitsche (I924) has described labrets. 
Painted decorations on specimens collected in recent years, though based on simple elements, exhibit a complexity of rhythm scarcely to be expected among people of such general cultural poverty. A study of the designs has shown that they can be divided into two major groups. The more recent of these shows apparent connection with textile patterns of the Araucanians, although the relationship is too vague and the available material too scanty for exact demonstration. The Araucanians, it will be recalled, in the sixteenth century occupied only a few small valleys east of the Andes, but in the eighteenth century they overran most of the Pampas, thus coming into contact with the Tehuelche.

We also have given reasons for believing that the Tehuelche formerly adorned their robes with designis of a different type, related to the art of other nomadic tribes, such as the Charrúa, and until recently found in the Chaco. This school of decoration we believe is basic over a large area in South America, for it is typical of archeological remains not only from Patagonia but as well from the Pampas, from the Calchaquí region, the lower Paraná, and from the Gran Chaco.

The absence of such decorative motives among the Ona and Haush of Tierra del Fuego implies that they had been separated from their mainland kinsmen for many centuries, and it raises the question whether the Tehuelche carried this type of design with them when they populated Patagonia or whether it reached them by infiltration at a later date.

\section{BIBLIOGRAPHY}

Ambrosetti, J. B.

I90 I Arqueología Argentina. Hachas votivas de piedra ... In Anales del Museo Nacional de Bucnos Aires, t. viI, Buenos Aires.

1902 Arqueología Argentina. Un nuevo pillan-toki. In Revista del Museo de La Plata, t. x, La Plata.

1904 Arqueología Argentina. Insignia lítica de mando de tipo Chileno. In Anales del Musco Nacional de Bucnos Aires, t. XI (3 ser., t. IV), Buenos Aires.

Bourne, B. F.

I853 The captive in Patagonia; or life among the giants. Boston. Bruch, Carlos. See Outes and Bruch. 
CoOper, I. M.

I925 Culture diffusion and culture areas in southern South America. In XXI Int. Congr. Anler., Göteborg.

FALKNER, Thomas

I774 A description of Patagonia and the adjoining parts of South America. Hereford.

Fletcher, Francis

I854 The world encompassed by Sir Francis Drake, collected out of the notes of Master Francis Fletcher preacher . . . and others. In Haklu.

Giglioli, E. H.

I903 Intorno a due singolari oggetti ceremoniali litici dall' America australe ... In Archizio per l'Antropologia e la Etnologia, vol. xxxiri, fasc. $3^{\circ}$, Firenze.

Holmes, IV. H.

I9r2 Stone implements of the Argentine littoral. In Bull. 52, Bur. Amer. Ethnl., Washington.

LAdrillero, J. F. de

I880 Relación del riaje al estrecho de Magallanes. In An. hidr. mar. Chile, t. vi, Santiago.

Lafone Quevedo, S. A.

I905 Viaje arqueológico en la región de Andagala. In Revista del Museo de La Plata, t. xiI, La Plata.

LEHMANN-Nitsche, R.

I904 Études anthropologiques sur les indiens Takshik (groupe Guaicuru) du Chaco Argentin. In Revista del Museo de La Plata, t. xi, La Plata.

I909 Clavas cefalomorfas de piedra procedentes de Chile y de la Patagonia. Ibid., t. Xvi (2 ser., t. III), Buenos Aires.

I909a Hachas y placas para ceremonias procedentes de Patagonia. Ibid.

I9i6 Nueras hachas para ceremonias procedentes de Patagonia. In Anales del Museo Nacional de Historia Natural de Buenos Aires, t. xxvin, Buenos Aires.

I924 Piedras labradas para el labio y el lóbulo y collares de conchas procedentes de la Patagonia septentrional. In Comunicaciones del Musco Nacional de Historia Natural de Buenos Aires, t. II, no. I3, Buenos Aires.

L.ooser. Walter

192- Araucanian textiles. In Chile, Jan,-Feb., New York. LOTHROP. S. K.

I928 Indians of Tierra del Fuego. In Contr. Mus. Amer. Ind., Hey'e Fdn., vol. x, New York. 
Musters, G. C.

r87 I At home with the Patagonians. London.

NoRdexskiöLd, Erland

I903 Präcolumbische Wohn- und Begräbnisplätze an der SüdWestgrenze von Chaco. In Köngl. Svenska VetenskapsAkad. Handlingar, Bandet 36, no. 7, Stockholm.

I9I9 An ethno-geographical analysis of the material culture of two Indian tribes in the Gran Chaco. In Comparative Ethnographical Studies, vol. I, Göteborg.

Nuño da Silva

I906 The relation of a voyage. In Hakluyt, Principal Navigations, vol. xi, Glasgow.

D'Orbigny, A.

I839 L'homme américaine. 2 vols. Paris.

Outes, F. F.

I904 La alfarería indígena de Patagonia. In Anales del Museo Nacional de Buenos Aires, t. XI (3 ser., t. Iv), Buenos Aires.

I905 La edad de piedra en Patagonia. Ibid., t. xis (2 ser., t. v), Buenos Aires.

Igo8 Arqueología de San Blas. Ibid., t. xvi (3 ser., t. III), Buenos Aires.

I916 Las hachas insignias Patagónicas. Examen crítico del material conocido y descripción de nuevos ejemplares. Buenos Aires.

I9i6a Las placas grabadas de Patagonia. Examen crítico del material conocido y descripción de nuevos ejemplares. In Rezista de la Universidad de Buenos Aires, t. xxxir, Buenos Aires.

Outes, F. F., and Bruch, Carlos

I9ro Los aborígines de la República Argentina. Buenos Aires.

Oviedo y Valdes, G. F. de

I $85 \mathrm{I}-55$ Historia general y natural de las Indias, islas y tierra-firme del mar océano. 4 vols. Madrid.

Pernetty, J. A.

I770 Histoire d'un voyage aux Isles Malouines. 2 vols. Paris. Pigafetta, Antonio

I906 Magellan's voyage around the world. 2 vols. Cleveland. Spegazzini, Carlos

1884 Costumbres de los Patagones. In An. soc. cicnt. Argentina, t. xiv, Buenos Aires. 
TORRES, L. M.

19I I Los primitivos habitantes del delta del Paraná. Buenos Aires.

Verneau, R.

I903 Les anciens Patagons. Monaco.

Verneau, R., and Vaulx, E. de la

1902 Les anciens habitants des rives du Colhué Huapí. In XII Intern. Congr. Amer., Paris. 


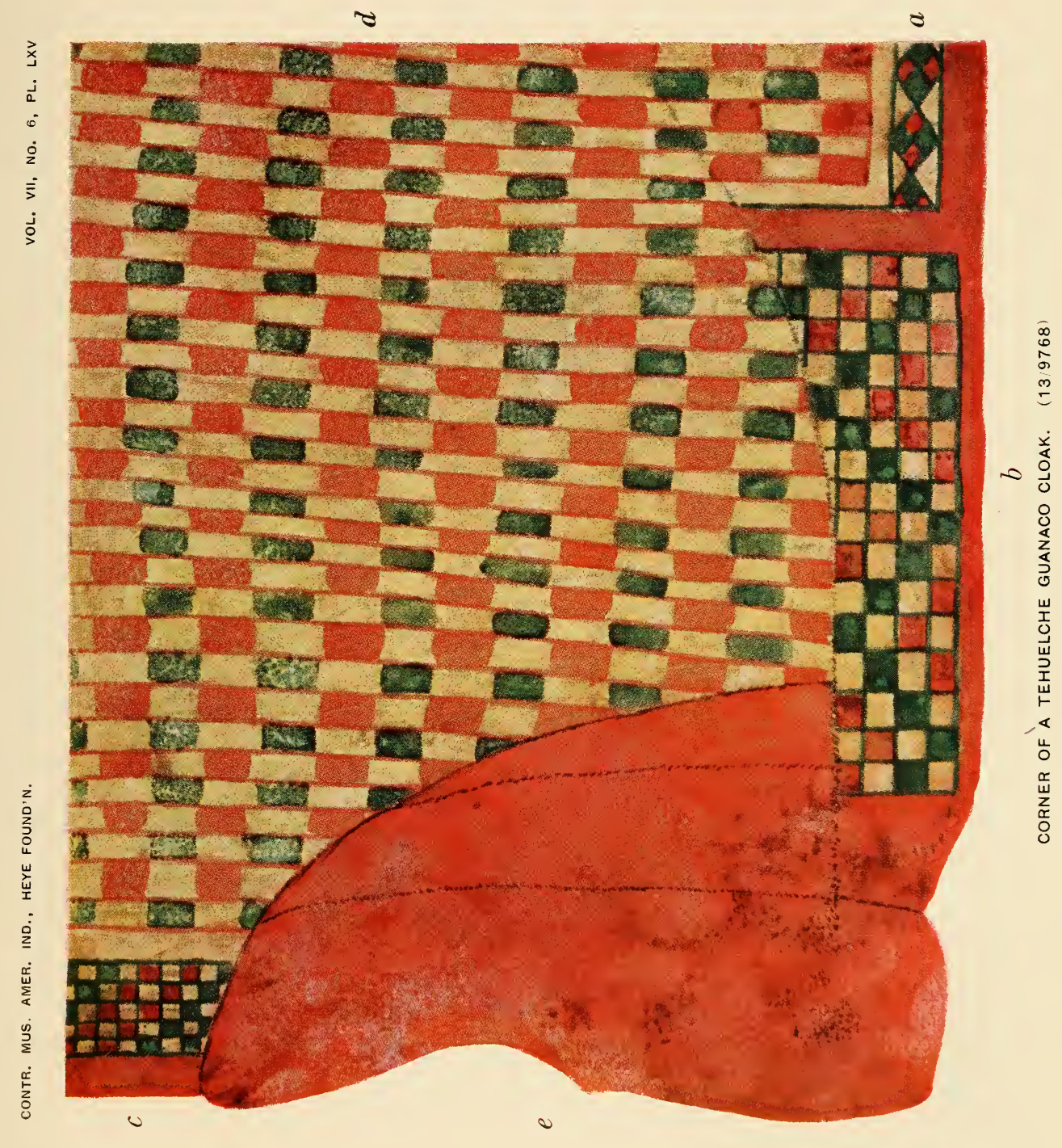





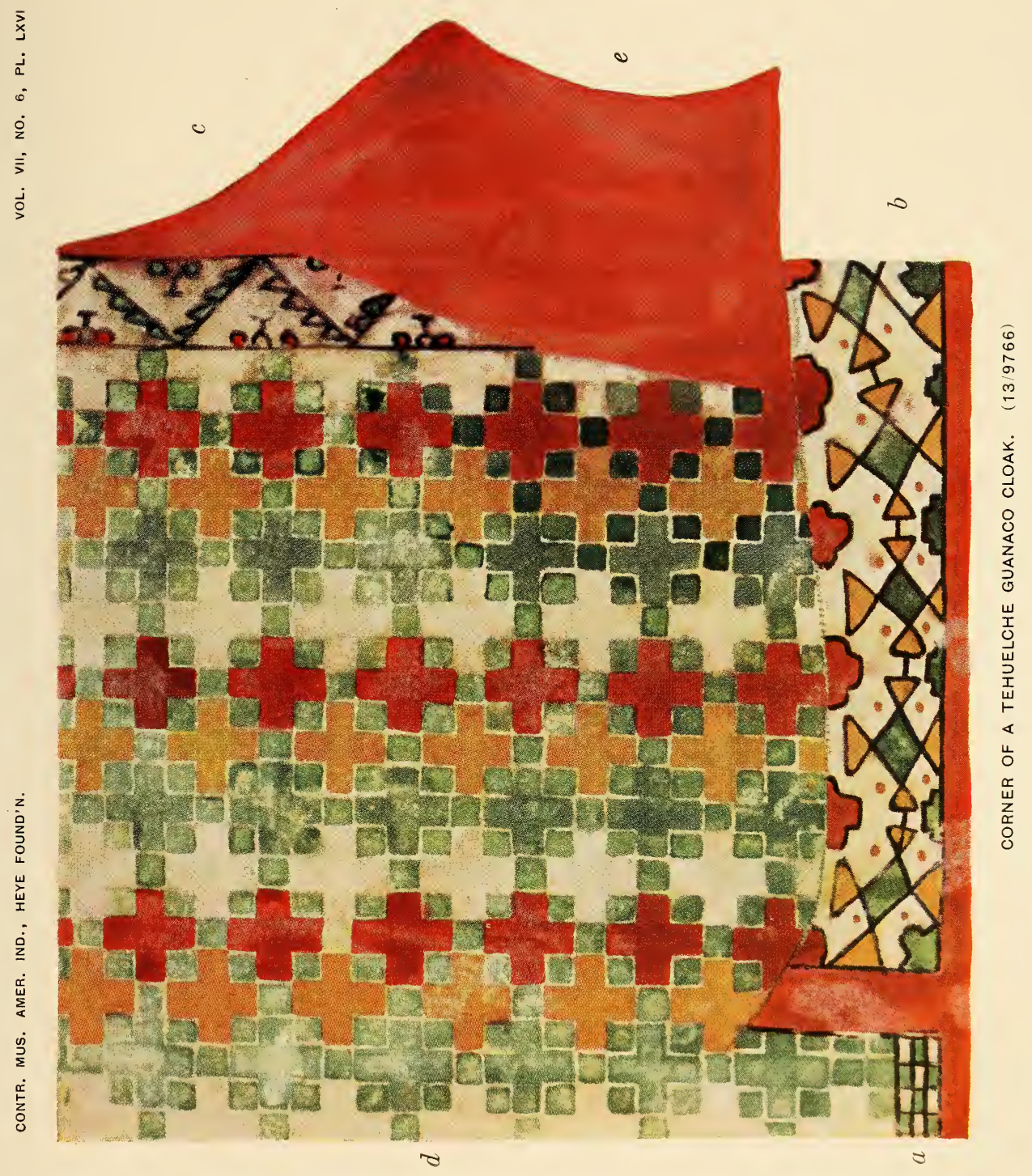







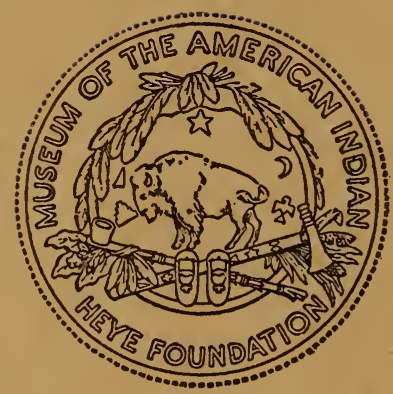

